\title{
Sciendo
}

\section{Pre-Hispanic Nahua Slavery}

\author{
PETER VYŠNÝ \\ Department of Legal History, \\ Trnava University, Trnava, Slovakia \\ petervysny@hotmail.com
}

\begin{abstract}
The article deals with pre-Hispanic Nahua slavery. Based upon an examination of Nahua perception of slavery/slaves, Nahua forms of slavery (apart from the slaves destined for sacrifice there were slaves destined for work) and the social and legal position of Nahua slaves (destined for work) the author concludes that the Nahua institution traditionally called "slavery" is different from its counterparts known from the history of Occident. Except for slaves destined for sacrifice to the gods which are discussed only briefly in the article, the Nahua slaves (i.e. the slaves destined for work) had a certain degree of personal freedom and certain rights. Becoming a slave at birth was possible only exceptionally and the enslavement of persons was in many cases (even if not in all cases) only temporary. The treatment of Nahua slaves - compared to the living conditions of their counterparts in many other world cultures - was significantly better, more humane. This can be seen from the fact that the master was entitled only to his/her slave's labor and not to slave's life, health, family members or property, as well as from the fact that the slave could obtain freedom in many ways, not only by the manumission made by his/her master. Although slaves were considered a kind of both physically and mentally "less perfect" individuals who were "dirtied", that is, morally tainted and dishonored by their enslavement and its reasons (mainly a delinquent behavior, i.e. non-payment of debts or perpetration of certain crimes), they were not systematically excluded from the wider society formed by free persons and they lived with their families in their houses and neighborhoods.
\end{abstract}

KEY WORDS: Aztec Empire, essential features, Nahua Culture, pre-Hispanic era, slavery 


\section{Introduction}

The Nahua ${ }^{1}$ term tlacohtli (pl. tlacotin/tlatlacotin) was translated by the authors of colonial written sources, created after the Spanish conquest of Aztec Empire ${ }^{2}$ in the $16^{\text {th }}$ and $17^{\text {th }}$ centuries, as a "slave" (esclavo, siervo). It was motivated, inter alia, by the intention of some authors to prove that slavery existed already in pre-Hispanic society and thus to support the introduction of certain forms of Indians' forced labor in colonial society. This labor resembled slavery in such a considerable extent that von Mentz (2007) has aptly denoted them "semi-slavery" ("semiesclavitud").

On the other hand, the authors of colonial sources were aware of the fact that the translation of the term tlacohtli as "slave" is not entirely appropriate, as Nahua slavery (tlatlacoliztli) differed to a large extent from the medieval European notion and forms of slavery, with which they were familiar. ${ }^{3}$ Based on Las Siete Partidas (Seven Parts), the most important source of

Nahuas, sometimes referred to as Aztecs, were the dominant native culture of Mesoamerican area called "Central Mexico" (Valley of Mexico and its surroundings). There were about twenty Nahua ethnic groups (SMITH 2012:4) residing in their autonomous city-states (altepeme; sg. altepeth), most of which became part of the Aztec Empire.

2 Aztec Empire existed from the second quarter of the $15^{\text {th }}$ century to 1521 in approximately presentday central and southern Mexico (except for certain areas there, e.g. the Mayan areas). It reached an area of about $278.852 \mathrm{~km}^{2}$, but only the area of about $40.000 \mathrm{~km}^{2}$, including the central zone of the empire (the Valley of Mexico with an area of about $7.000 \mathrm{~km}^{2}$ ), was systematically administered. The empire had a population of five to six million, with about a million of them living in the central zone of the empire (FARGHER - BLANTON 2007:867-868). The empire had three cooperating centers, which were the neighboring and allied Nahua city-states of Tenochtitlan, Tezcoco and Tlacopan (all were located in central part of the Valley of Mexico), of which Tenochtitlan became the most important over time.

3 For example, according to the Franciscan friar Toribio de Benavente Motolinía, "The making of slaves among these natives of New Spain is very contrary to the nations of Europe ... and it still seems to me that those who are called slaves (in Mexico) lack many conditions to be properly slaves" ("El hacer de los esclavos entre estos naturales de la Nueva España es muy contrario de las naciones de Europa... y aún me parece que estos que llaman esclavos (en México) les faltan muchas condiciones para ser propiamente esclavos") (MOTOLINIA 1970:170). Bartolomé de Las Casas, a Dominican, bishop and official protector of Indians appointed by the Spanish Crown, has also emphasized a specific nature of Nahuas' and other Indians' pre-Hispanic slavery: "[t]his term slave, among the Indians does not denote or mean what among us; because it does not mean but a servant or person who has some more care or some more obligation to help me and serve me in some things that I need. Being an Indian slave... was very little less than being a son [of the slave master], because the slave had his house, property, wife and children and he was enjoying his freedom like other free people, his neighbors, unless he had to work in his master's house or on his master's field or to do other similar things for him that were done but in certain periods of time and many of them but occasionally, and all the other time he had for himself and enjoyed it for himself just like free people did. Beyond that, the masters treated such slaves very softly, as if they owed them nothing. And thus, beyond comparison they were freer than those who were called

DOI: 10.2478/eas-2021-0012 @ University of SS. Cyril and Methodius in Trnava. All rights reserved. 
Peter VYŠNÝ

Pre-Hispanic Nahua Slavery

law in Castile at the time, with considerable authority in colonial Spanish America, the said notion and forms of slavery (servidumbre) can be briefly described as follows: The slavery was seen to be the most evil and despicable thing in the world after sin because it was contrary to the natural freedom with which every human being was endowed by God, which, however, did not prevent Castile or other medieval countries from practicing slavery, albeit to a limited extent. To become a slave was possible by being born from a slave woman (wether the father was a slave or was a free person, was irrelevant), by voluntarily selling himself into slavery in order to pay debts (the creditor became the master of the enslaved debtor), or by being captured in a just war waged by Christians in order to defend and spread their faith (in the concrete, the enslaved ones or cativos were non-Christian warriors, captured by Christian warriors). In principle, the slave status was lifelong, however, there were several ways in which a slave could be released (a slave could be given freedom by his master and moreover the slave could obtain it by himself, for example, if he denounced the commission of certain crimes against the king or married a free person). An essential feature of a slave was that he lacked personal freedom and was subject to the power of his master (who was a free person). Such power was extensive, but not unlimited - the master could not arbitrarily kill the slave or punish him too harshly (physically). The main task of a slave was to work for the master. If a slave acquired a certain property, this property belonged to his master automatically. Although a slave was juridically a thing that pertained to the fortune of his master (i.e. a slave was not a subject but an object of law), he had certain minimum of rights, namely: the right to the protection of his life and health and to the good treatment by his master - a slave oppressed by his master could complain to a judge who could sell him to another master; the right to marry with both a slave or a free person; and the right not to assume responsibility

serfs. And this is also very clear and very notorious, especially to the clergymen who have penetrated the languages and dealing with this matter, with diligence they have inquired it and got well acquainted with it" ("...este término esclavo, entre los indios no denota ni significa lo que entre nosotros; porque no quiere decir sino un servidor o persona que tiene algún más cuidado o alguna más obligación de ayudarme y servirme en algunas cosas de que tengo necesidad. Por manera que indio ser esclavo de indios era muy poco menos que ser su hijo, porque tenía su casa y su hogar y su peculio y hacienda, e su mujer e sus hijos y gozar de su libertad como los otros súbditos libres sus vecinos, si no era cuando el señor había menester hacer su casa o labrar su sementera, o otras cosas semejantes que se hacían a sus tiempos, y muchas de cuando en cuando, y todo el demás tiempo tenía por sí y dél gozaban para sí, como personas libres. Allende de aquello, el tratamiento que los señores hacían a los tales siervos eran blandísimo e suavísimo, como si nada les debieran. Y así, sin comparación eran más libres que a los que llaman los derechos originarios y ascripticios. $Y$ esto también es clarísimo y muy notorio, en especial a los religiosos que han penetrado las lenguas e de industria lo han inquerído y bien sabido tratando desta materia") (LAS CASAS 1552). 
for e.g. damage caused by acts performed by the slave while working for his master according to his orders (see LAS SIETE PARTIDAS 1555: Qvarta, Partida, titulos V, XXI-XXIII).

Not only the authors of colonial sources but also modern researchers were aware of the fact that pre-Hispanic Nahua slavery deviated from the standard occidental understanding of slavery (see SHADOW - RODRÍGUEZ 1995). For example, Moreno (1931), Vaillant (1941) and Bosch García (1944) considered its rather humane character to be an important specificity of Nahua slavery. Other researchers, such as Katz (1956), Castillo Farreras (1996 [1972]) and Hicks $(1974,1976)$, pointed out that the number of tlatlacotin was relatively low, that slave labor was not the basis of the economy, that in most cases the slave status was not a lifelong one, that tlatlacotin were not deprivated of personal liberty in full and were not separated from their families, nor have they been systematically excluded from the wider society, etc. Other researchers, such as González Torres (1985) and Clendinnen (1991), took a closer look at slaves who were not destined for work but for ritual execution, that is, they were sacrificed to the gods. Last but not least, Ana Luisa Izquierdo (1984) has examined the pre-Hispanic slavery in a broader Mesoamerican context, since this institution existed not only in Nahua society, but also in other Mesoamerican native societies, for example, in Maya society.

Since pre-Hispanic Nahua slavery corresponds only to a limited extent to the occidental concept of slavery outlined above, which the authors of colonial sources and, to varying degrees, modern researchers have used as a general frame of reference, it is necessary to begin the present article on pre-Hispanic Nahua slavery by reconstruction of its authentic notion, which I will try to do, without any claims of completeness, in the article's first part. In the next part of the article, I will examine the forms of Nahua slavery, while also dealing with the social and legal position of slaves. However, I will only very briefly mention the situation of slaves destined for sacrifice to gods, focusing in more detail on other category of slaves, those who were destined for work. In the conclusion, I will summarize the essential features of the pre-Hispanic Nahua slavery. The exposition of the article's topic is preceded by a brief note on the nature of the sources processed in the article.

\section{A Note on Sources}

Besides the secondary literature, the article is based on selected colonial written sources. The credibility and informative potential of these sources are limited by various factors (for more 
details see e.g. VYŠNÝ 2019:37ff.). For the purposes of the present article, it is sufficient to mention but two typical attributes of the sources.

First, the sources have a hybrid nature. Such a nature of the sources (individual sources are characterized by it to varying degrees) stems from their foundation on both indigenous (Nahua) and Spanish (European, Christian) terminologies, concepts and political, legal, economic, religious and cultural traditions, as well as on their syncretic forms (see e.g. LEVIN ROJO - NAVARRETE LINARES 2007; ROMERO GALVÁN 2011). It follows that the source representations of slavery, like those of other institutions of pre-Hispanic Nahua society, may be distorted as well as inaccurate and incomplete to some extent, since the authors of the sources have extensively described the pre-Hispanic Nahua culture in terms of their own, i.e. Spanish (European, Christian) culture. In addition, the authors of colonial sources who where not Spaniards, but Nahuas (Nahua elites or authorities and scribes of Nahua local self-governing communities) introduced the pre-Hispanic Nahua society not only from perspective of their own, i.e. Nahua culture, but also in the light of Spanish (European, Christian) culture, or rather in the light of their (mis)interpretation of this dominant culture. Last but not least, colonial sources involve translations of various Nahua words, expressions or terms into (Castilian) Spanish and vice versa which are more or less problematic (e.g. too much simplified) in many cases (see e.g. CASTILLO FARRERAS 2010). Thus, so-called double mistaken identity can be attributed to the source texts, including those that inform about slavery. Double mistaken identity is a phenomenon related to the postconquest Nahua culture, identified and studied by James Lockhart (1985; 1992), who defines it as follows: "[e]ach society/culture [i.e. the Spaniards and the Nahuas] approached the other in a similar fashion, manifesting relatively little interest in the other side's internal structure, apparently expecting it in some way to mirror its own. The unspoken presumption of sameness showed itself above all in the way each used its own categories in interpreting cultural phenomena of the other. Probably the same principle was at work, on both sides, with all the peoples the Spaniards encountered, but in this case, more perhaps than in any other, similarities between the two cultures reinforced the tendency. At the root of cultural interaction between Nahuas and Spaniards was a process I have called Double Mistaken Identity, whereby each side takes it that a given form or concept is essentially one already known to it, operating in much the same manner as in its own tradition, and hardly takes cognizance of the other side's interpretation. Each could view Indian town government, the monastery complexes, mural painting, land tenure, and many other phenomena of the postconquest Nahua world as falling within its own frame of reference. Under the unwitting truce thus created, Nahua patterns could continue indefinitely in a superficially Hispanic guise that was sometimes no more than a label. Then, over the centuries, without much 
Peter VYŠNÝ

Pre-Hispanic Nahua Slavery

obvious surface change, a rapprochement took place in many spheres, often leading to forms that cannot be securely attributed to either original parent culture, but that were accepted all long as familiar by both. Even when the end result looked more Hispanic than indigenous, the Nahuas, without second thoughts and with good reason, regarded the concept, pattern, or institution as their own" (LOCKHART 1992:445-446).

Second, the sources that inform on pre-Hispanic Nahua slavery in a more comprehensive way mostly refer only to the central zone of the Aztec Empire (roughly the Valley of Mexico) and, in particular, to its first (city-state of Tenochtitlan) and second (city-state of Tezcoco) most important centers. In other words, the sources relevant to this article do not concern explicitly the entire area of the pre-Hispanic Nahua culture (approximately the Central Mexico composed of the Valley of Mexico and its surroundings). However, it is possible, at least to some extent, to reconstruct upon these sources such essential features of slavery that could in principle be shared virtually by all Nahuas. This is due to the fact that many source data are generalized and thus may cover implicitly the pre-Hispanic Nahua culture as a whole. Moreover, the pre-Hispanic Nahua slavery, although it may have differed in some details in specific Nahua localities and regions, seems to have had much the same nature in the entire area of the pre-Hispanic Nahua culture (cf. e.g. BERDAN 2014:190-191; LOCKHART 1992:99-100) which thus allows us, at least partially, to examine this slavery using sources explicitly related mostly only to the central zone of the Aztec Empire.

\section{Nahua View of Slavery}

The noun tlacohtli, i.e. "male slave" (esclavo) or "female slave" (esclava), is made of root tlaco and suffix -tli. The same root can be combined with the suffix - $t$, but the word tlacotl has a completely different meaning than tlacohtli, to wit: "spear" (jara) or "stick, rod" (verdasca) (CASTILLO FARRERAS 2010:58).

The root of the expression tlacohtli, i.e. tlaco, can be translated as "half, middle, center" (mediano, que ocupa el centro, que está a la mitad, en medio) (KARTUNNEN 1992:260). Following Castillo Farreras (1996:119-121) we can deduce that Nahua tlatlacotin were perceived as people located, so to speak, between the two strata of Nahua society, a tiny elite class (pipiltin) and the mass of commoners (macehualtin). Related to this situation of tlatlacotin was a belief that Tezcatlipoca, an important, ubiquitous and omnipotent Nahua 
god, also known as Titlacahuan (We are his slaves), ${ }^{4}$ did not "ridicule" of the tlatlacotin, that is, he did not influence, whether in a positive or negative sense, their destinies, as he arbitrarily was doing with those of pipiltin and macehualtin. In addition, Tezcatlipoca was believed to protect tlatlacotin, his "beloved children", from ill-treatment by their masters and anyone else, although he probably did not provide them protection permanently, but only once every 260-day calendar cycle (tonalpohualli), around the day called ce miquiztli (onedeath), associated with a special worship of Tezcatlipoca (cf. SAHAGÚN 2001, I:327-328). Castillo Farreras (1996:121) explains the said attitude of Tezcatlipoca towards the tlatlacotin by their mutual neutral or peaceful relationship - Tezcatlipoca gave or owed the tlatlacotin nothing and the slaves did not owe him anything. In contrast, pipiltin, as well as the rich merchants (pochteca), owed Tezcatlipoca because he had given them considerable wealth, while also providing pipiltin with political power (military and civil offices). The god could therefore monitor their behavior to see if they were handling the property and power they had been given by him properly, and if he was not satisfied with them or he just liked it, he could "ridicule" of them, which specifically meant throwing them into poverty, depriving them of their offices and the like. Macehualtin, like tlatlacotin, were not provided by god with wealth or power, but macehualtin, unlike tlatlacotin, were perceived as a people to whom Tezcatlipoca owes something (although in reality he would give them nothing except if he sometimes would like to do it). Thus, while there was no obligation in the relationship between Tezcatlipoca and the tlatlacotin on its either side, in the relationship between Tezcatlipoca and the pipiltin or the merchants it existed on the side of the pipiltin and merchants, and in the relationship between Tezcatlipoca and the macehualtin it existed on the side of god.

The word tlacohtli is close to the noun tlahtlacolli, i.e. "sin, fault" (pecado, culpa, defecto) (KARTUNNEN 1992:263), which can also be translated as "delict" or "crime", since the authors of the colonial sources generally identified sin with crime (see JOHANSSON 2010). These authors followed the contemporary Spanish/European understanding of crime, created under the influence of canon law in the High to Late Middle Ages, according to which a crime was an act directed not only against a specific individual, the injured or killed victim of the crime, but also against the whole society and its internal order which was considered optimal and was guaranteed, as well as maintained by God and the ruler. Therefore, the perpetrators in most cases could not atone for the commission of crimes and their negative 
consequences (only) by compensating the victims or victims' surviving relatives. They should (also) be punished so that they provided a symbolical (moral) satisfaction to the society for harms they had caused to it by their crimes. That was achieved by imposing penalties that made suffer the sentenced criminals both physically and mentally, dishonored them, separated them from their families and communities and the like, letting them feel physically that what they had done was wrong. Thus, the affliction of the condemned persons became the standard way to expiate their crimes. That way had a symbolical, moral nature, like in the case of the atonement of sin by the sinner (see e.g. LÓPEZ-AMO Y MARÍN 1956).

Johansson (2010:passim) considers the identification of the Nahua expression of tlahtlacolli with the Christian concept of sin inappropriate. Tlahtlacolli was not perceived, unlike sin, as an abstract evil in itself, but as a violation of a concrete social/legal norm, having a concrete form perceptible to human senses, for example, the form of material damage. In addition, tlahtlacolli could not be atoned for by its remission by divine beings. Therefore, the identification of the Nahua ritual of neyolmelahualiztli ("the act of straightening the heart") with Christian (Catholic) confession which occurs in the sources is incorrect. Perpetrators of sexual crimes (e.g. adultery) were punished by death, but they could avoid their punishment performing the neyolmelahualiztli ritual or, according to the authors of colonial sources, "confessing themselves", in front of a priest serving in the temple of the rain goddess Tlazolteotl. Such a ritual or "confession" individuals had the right to perform only once in a lifetime whereupon they allegedly practiced it until a later age or at the end of life. However, there was no confession in its Christian (Catholic) understanding in the Nahua society: the task of Tlazolteotl was not, from the position of a divine being, to forgive a sin (after its confession and repentance by the sinner) but to supernaturally absorb the crime, thus eliminating it and its harmful consequences. The Nahuas imagined this activity of Tlazolteotl as the consumption of a crime by the deity. Since they figuratively compared the crime to excrement, it was actually a "ritual coprophagy".

The expression tlahtlacolli, not identified with the culturally specific notion of sin and understood as a designation for a delict, is closely related to the word tlacohtli not only for linguistic reasons, but also due to the existence of enslaved delinquents as an independent category of Nahua slaves (see bellow).

The word tlacohtli is also associated, although not linguistically (CASTILLO FARRERAS 1996:119), but socially, with the noun tlacohualli, i.e. "a purchase, something bought" (cosa comprada) (KARTUNNEN 1992:255). Slaves, especially those destined for ritual execution, were traded throughout the Nahua area and beyond it. Thus, the connection between the terms tlacohtli and tlacohualli is justified. 
Peter VYŠNÝ

Pre-Hispanic Nahua Slavery

The Nahua view of slavery can be approached not only by examining the social meaning of the word tlacohtli and related expressions, but also in the context of Nahua general understanding of a human being (see GARZA 1978).

For the Nahuas, a human as such was a being inhabiting the terrestrial world, which distinguished him/her from the gods, who existed not only in the terrestrial world but also in extraterrestrial worlds, the heavens and the underworld, which were inaccessible to humans (LÓPEZ AUSTIN 2015:26).

Furthermore, humans also differed from the gods in that they had a dual nature. Their first essence was the body. This essence, which the gods did not have, was material and temporary. In contrast, the second essence of humans and at the same time the only essence of the gods was immaterial (spiritual) and perpetual. This essence took the form of certain supernatural energies (substances), which in the case of humans resided inside their bodies. The main supernatural energies were: the tonalli residing in the head of a human and the teyolia residing in his heart (LÓPEZ AUSTIN 2015:27ff.; for more details see LÓPEZ AUSTIN 2004). We could roughly compare these energies to what is understood as a soul in the West (also because of their divine origin). On the other hand, Nahuas not only considered them for a soul, i.e. for a part of the human body, but also identified them with various phenomena of the real world. Nahuas explained, for example, sunlight, wind or the spread of a certain smell or odor in the air, as well as childbirth, psychosomatic development and death of a person etc., as processes consisting in a certain actuation, transformation or flow of the respective supernatural energies (see McKEEVER FURST 1997).

Nahuas seem to have considered enslaved people to be physically and mentally "degenerate" or "sick", as they believed that after becoming tlatlacotin they lost, at least in part, their supernatural energies (especially the tonalli and teyolia), which harmed their body, disrupting its internal balance and reducing its functionality. Tlatlacotin were thus perceived as people who were biologically less perfect than free people, which justified their subordinate position in society. At the same time, they were considered "dirtied" people, that is people who were morally tainted and dishonoured with their enslavement and its reasons, among which the delinquent behaviour, either non-payment of debts or the commission of certain crimes, was the predominant one. In this context, it is possible to recall the linguistic proximity of the terms "slave"(tlacohtli) and "delict" (tlahtlacolli), as well as the fact that Nahuas figuratively identified delict/crime with impurity or excrement. Being tlatlacotin "dirty" humans, they could be released from slavery and become free persons (at least in some instances) only after they had been ceremoniously bathed in water that "washed away" their "dirt". However, this was not the case for tlatlacotin destined for sacrifice who did not gain freedom but cultic 
purity, a prerequisite for their ritual execution, by their bath. Freed tlatlacotin became physically and mentally normal people again and their moral taint and dishonour disappeared (see LÓPEZ AUSTIN 2004:461ff.).

Last but not least, Nahuas viewed the slave status of a man or woman as his or her predestination (fate), resulting from the fact that the date of his or her birth was, according to the calendar, unfavorable.

There were two basic, concurrent calendar cycles. The first was the civil calendar xiuhpohualli (xihuitl) which was a solar calendar. It included 365 days, of which 360 were divided into eighteen "months" of twenty days each (veintenas); the remaining five days (nemontemi) of the year did not belong to any "month", and were considered redundant, unfortunate and dangerous. In each of the eighteen time periods, a different major religious holiday was celebrated. The second calendar had a ritual and divinatory character and was called tonalpohualli. It included 260 days. It consisted of two cycles, one comprising thirteen days, numbered 1 to 13 , and the other twenty days, which were named after animals, plants, natural phenomena or abstract concepts. Both cycles run in parallel, so there were $13 \times 20=$ 260 combinations of numbers of days from the first cycle and names of days from the second cycle, which were used to denote individual days (PREM 1990:241-243).

Each of the combinations used to denote days within tonalpohualli gave certain characteristics to the denoted days. The day could be (in various respects) favorable or unfavorable, or indifferent. Of particular importance was the nature of the day of birth, on the basis of which the future character traits and life-styles of newborns were predicted. The calendar could reveal via a professional astrologer that a newborn would be rich or poor, would occupy a high or a low social position, would be a good person or a drunkard, gambler, adulterer, thief or other offender, would become a tlacohtli, would be sacrificed to gods, etc. (BOONE 2007:29ff.; SAHAGÚN 2001, I:313ff.).

Thus, the Nahuas believed that the fate of each individual is determined by the nature of the day of his/her birth. In addition, they believed that various gods interfered differently in people's lives and were the cause of various positive and negative phenomena that people encountered during their lives. Consequently, people's lives were going on according to the will of the gods, which people could not foresee or fundamentally influence. Although people would worship the gods in order to gain their favor and aid, the rituals and behaviors that served to do so would not be effective in every single case (HINZ 1992:55-75).

On the other hand, it can be stated that the Nahua worldview was not completely fatalistic. It was believed that a person with an unfavorable fate can alleviate it significantly (even if not 
Peter VYŠNÝ

Pre-Hispanic Nahua Slavery

reverse it completely) by permanent self-control. It means, by suppressing the negative aspects of his/her personality and everyday ethically correct decision-making and actuation, as well as subordinating his/her interests and needs to the interests and needs of society, fulfilling his/her duties, taking proper care of his/her family, etc. (LEÓN-PORTILLA 1993:189-202).

There were also special methods to "improve" the evil destinies of individuals. For example, if a child was born on an unfavorable day, the unfavorable fate that threatened him/her was alleviated by the fact that his/her birth was formally celebrated (the child was washed or "baptized" according to the colonial sources and was given his/her name) on a favorable day (SAHAGÚN 2001, I:356, 361, 571ff.). People who experienced a "bad omen“ during their lives, which was considered to be a confirmation of their unfavorable fates resulting from unfavorable dates of their birth, talked about it with astrologers or priests and performed certain religious rituals on their recommendation, while awaiting an "improvement" of their destinies (SAHAGÚN 2001, I: 375-376).

It follows from the foregoing that the Nahuas viewed tlatlacotin as a kind of "incomplete" or physically and mentally "less perfect", that is, as "degenerate" or "sick" people. Moreover, the tlatlacotin were seen as "dirtied" people, that is, as people who were morally tainted and dishonoured by their enslavement and its reasons, the main one of which was their delinquent behaviour (non-payment of debts or committing certain crimes), figuratively understood as impurity or excrement. On the other hand, as soon as the tlatlacotin regained their freedom, for the Nahuas, they became physically and mentally normal people again, and their moral taint and dishonour disappeared.

Tlatlacotin were also perceived as people who did not belong to none of the two strata of Nahua society (pipiltin and macehualtin). As we shall see in the next part of the article, this, however, did not mean that they were excluded from the broader society formed by free persons. Moreover, they lived with their families in their houses and neighborhoods, with one exception: many tlatlacotin destined for sacrifice were foreigners imported to the places of their ritual execution from abroad. 
Peter VYŠNÝ

Pre-Hispanic Nahua Slavery

\section{Forms of Nahua Slavery}

Among the Nahua the slave status was not hereditary, except for both male and female descendants to the fourth generation and other relatives of executed traitors of the state/ruler ${ }^{5}$ and the institution of huehuetlahtlacolli, described below.

Nahua tlatlacotin can be divided into two basic categories, to wit: 1. tlatlacotin destined for sacrifice to the gods and 2. tlatlacotin assigned to work for their masters (see e.g. TRIGGER 2007:157ff.).

The dividing line between the two categories of tlatlacotin seems to have been permeable. For example, the tlatlacotin destined to sacrifice were not supposed to work before their ritual execution (CASTILLO FARRERAS 1996:124-125), however, the enslaved prisoners of war were sometimes sacrificed several years after their capture, in Tenochtitlan, the capital of the Aztec Empire, sometimes even more than ten years after their capture (CERVERA OBREGÓN 2017:82), on the basis of which it can be assumed that they had done some work until they were ritually executed. In addition, the so-called "incorrigible slaves" (see below), as well as impoverished or indebted individuals who sold themselves into the slavery, despite of their usual assignment to work, could occasionally end up as human sacrifices to the gods (BERDAN 2014:190).

\section{Slaves Destined for Sacrifice}

As mentioned above, I do not deal in more detail with the tlatlacotin destined for sacrifice in this article, so I will only give some basic facts about them. The reason I proceed in this way is my opinion that the tlatlacotin destined for sacrifice were not slaves in the proper sense, for whom I consider, from a comparative historical perspective, only unfree laborers directly controlled by their masters and systematically working for them. Moreover, the tlatlacotin destined for sacrifice were, so to speak, "slaves of the gods", that is, they were not assigned to work for their human masters, although some seem to have worked for them prior their ritual execution.

The tlatlacotin destined for sacrifice were threefold: prisoners of war (mamaltin), slaves destined for sacrifice traded within the Aztec Empire (particularly in the marketplaces of 
Peter VYŠNÝ

Pre-Hispanic Nahua Slavery

Tenochtitlan and some other city-states located in empire's central zone $)^{6}$, and slaves given as a form of tribute to, for example, Tenochtitlan by some provinces of the Aztec Empire (see e.g. CLENDINNEN 1991:87ff; GRAULICH 2002).

In the Nahua society, a man who provided a tlacohtli to the priests in order they sacrificed $\mathrm{him} / \mathrm{her}$ thus increased his prestige (the handover of tlacohtli to sacrifice was a form of conspicuous consumption). Tlatlacotin were bought and offered for ritual execution mainly by wealthy merchants (pochteca) (see SAHAGÚN 2001, II:689ff.). They manifested with this that they were able to "nourish the gods" with human victims, which Nahuas and other Mesoamericans considered condicio sine qua non of the persistence and "functioning" of the world, in the same way as warriors recruiting from both pipiltin and macehualtin, who gained individuals to sacrifice on the battlefield. Providing of tlatlacotin to ritual execution by the merchants can thus be seen as a demonstration of their efforts to legitimize and strengthen their rather unstable social position: merchants were in disfavor of the elite (pipiltin), who saw them a kind of "nouveaux riches " trying to gain the same wealth, power and privileges as these elites had in a more simple way, that is, without the serious risk resulting from frequent participating in military expeditions.

\section{Slaves Destined for Work}

Friedrich Katz has estimated the number of Nahua tlatlacotin assigned to work to be about five percent of the population (KATZ 1989:277). Although this number cannot be sufficiently verified, it is indisputable that tlatlacotin formed rather a small social group with a significant fluctuation of its members (the slave status was not hereditary in most cases) and with a very limited contribution to the overall economy (SHADOW - RODRÍGUEZ 1995:320; SMITH - HICKS 2016:430).

Tlatlacotin worked as servants in the households of their masters doing housework like cleaning, sewing, grinding corn, cooking and the like, and/or they worked their masters' land.

$6 \quad$ The tlatlacotin destined for work were also traded to some extent. For example, the early colonial censuses of indigenous population of the Cuernavaca area in today Mexican State of Morelos (former pre-Hispanic Nahua city-state of Cuauhnahuac), dating from about 1540, inform that among the members of both elite and commoner families' households existing there were tlatlacotin in many cases, including those who were bought by households' heads from merchants who had brought them from abroad (see VON MENTZ 2007:544ff.). 
Peter VYŠNÝ

Pre-Hispanic Nahua Slavery

Moreover, they could perform construction work for their masters or carry goods of their masters (KATZ 1956:130-132; VON MENTZ 2007:547ff.).

Tlatlacotin were macehualtin of both sexes and any age: there were tlatlacotin who were adults in the juridical sense, ${ }^{7}$ as well as such who were not. Besides, tlatlacotin were both individuals and entire families. Also pipiltin could become tlatlacotin, but this was surely rare.

Three categories of tlatlacotin destined for work can be distinguished, to wit: 1. debtors enslaved due to their insolvency (debt slavery), 2. persons voluntarily enslaved by virtue of a contract (contractual slavery) and 3. enslaved perpetrators of certain crimes (penal slavery) (VYŠNÝ 2019:157). Let us look at the nature of each of these categories separately.

Debt Slavery. The institution of debt slavery can generally be described as follows: a debtor who failed to pay his/her debt properly and/or on time would convert into a slave of his/her creditor and would work for him/her until he/she has repaid his/her debt; however, sometimes the creditor in stead of using the workforce of the enslaved debtor would sell him/her to a third party. This way of dealing with debtors' insolvency has existed in various historical periods in many world cultures (see e.g. TESTART - JACOBS 2002), including the preHispanic Nahua culture, for which we have more detailed information on debt slavery practiced in the central zone of the Aztec Empire (roughly the area of Valley of Mexico) and particularly in its first (city-state of Tenochtitlan) and second (city-state of Tezcoco) most important centers (see MILLHAUSER 2017).

In the said zone, debt slavery appears to have been voluntary, that is, a debtor who had not repaid his/her debt properly and/or on time did not become a tlacohtli to his/her creditor ipso iure, i.e. automatically, but only on the basis of his/her special agreement with the creditor, by which the debtor was released from a prison for insolvent debtors (and other delinquents) called teilpiloyan (or: teilpilcalli) and was handed over to the power of creditor (KOHLER 2002:70, 110-111). Debt slavery thus arose by virtue of an agreement, that is, with the consent not only of the creditor but also of the debtor (creditor's future tlacohtli), however, in practice the debtor's conversion into the tlacohtli of his/her creditor was not entirely voluntary on debtor's part, since for the debtor to entry into slavery was the only way out of his/her unfavorable economic situation and especially from imprisonment.

$7 \quad$ Adulthood in the juridical sense was acquired mainly with marriage. Men used to marry 20 to 22 years old, women used to marry 15 to 18 years old (VYŠNÝ 2019:245).

DOI: 10.2478/eas-2021-0012 C) University of SS. Cyril and Methodius in Trnava. All rights reserved. 
The benefit of debt slavery to the creditor was that he/she could sell the enslaved debtor to a third party (DURÁN 2002, II:189) - in this case, unlike another case of slave sale (see below), the tlacohtli's consent to the sale was not required (KOHLER 2002:72-73) - and from the amount received he/she could satisfy his/her claim. However, the creditor could also agree with the debtor not to sell him/her, but to keep him/her as a tlacohtli, until he/she has repaid the debt by performing the work assigned to him/her by the creditor.

A large part of the enslaved debtors seem to have been gamblers (for example, the players of patolli table game which was very popular among both pipiltin and macehualtin) who bet and lost - not only their possessions but also their freedom (or the freedom of their close relatives) (for more details see AGUILAR-MORENO 2007:361ff.). Female prostitutes (ahuianime) also used to enter into slavery due to their debts (see e.g. LÓPEZ HERNÁNDEZ 2012).

The debt slavery can be distinguished from the enslavement of persons who failed to pay the tribute (in kind) to the state (after an additional time allowed for them to fulfill this duty had expired in vain), who could end up as human sacrifices to the gods (TORQUEMADA 1969:547).

Contractual Slavery. By virtue of a special contract a free person could sell himself or herself, as well as his/her close relatives (husband, wife, children) into temporary slavery in exchange for pieces of cotton cloth (quauchtli) and other premonetary currency (there was no money in the proper sense in pre-Hispanic Nahua society) or various foodstuff. There were three forms of this type of slavery, to wit: 1 . self-enslavement; 2 . the sale of a child into slavery by his/her parents; and 3. the institution of huehuetlahtlacolli.

Self-enslavement. A free person belonging to macehualtin could sell himself/herself into temporary slavery (IXTLILXOCHITL 1997, I:386) in order to improve his/her economic situation (and the economic situation of his/her family), which was done by concluding a special contract. This contract was concluded in a certain formal way, which had to be observed - otherwise the contract was invalid. In particular, for valid conclusion of the said contract the presence of at least four witnesses of both parties was required (MENDIETA Y NÚÑEZ 1992:88). These witnesses belonged to calpulhuehuetque, the members of council of elders, a self-governing body of the urban district (calpulli) in which the contract was concluded. They not only personally testified but also officially certified (and possibly recorded with Nahua writing) the conclusion of the contract, as well as made sure that the amount for which a person was sold into slavery was habitual, being twenty quauchtli such an amount (TORQUEMADA 1969:563). 
By virtue of the contract we are now examining the future master of the tlacohtli paid the agreed purchase price to his/her future tlacohtli without delay. As soon as the future tlacohtli had used, consumed or invested the received purchase price, which in individual cases could take more than a year, he/she became the tlacohtli of his masters and worked for him until he has paid the amount gained by his/her sale into slavery (KATZ 1989:280). The parties of the contract also agreed on specific work to be performed by the self-enslaved person (LÓPEZ AUSTIN 1961:74).

At first glance, it might seem that self-enslavement was identical to debt slavery. However, there was a difference between them. Self-enslavement arose from the decision to become a tlacohtli in order to obtain an economic benefit (a loan). Contrary, the enslavement of the debtor was the result of his/her previous insolvency. On the other hand, the contract of selfenslavement and the contract by virtue of which the insolvent debtor was converted into his/her creditor's tlacohtli took the same form.

From a juridical point of view, the fact that the person who sold himself/herself into slavery acted both as a subject and an object of the juridical relation established between him/her and the person who acquired him/her as a slave is somewhat embarrassing. In this context, it can be noted that a husband could also sell his wife into slavery and vice versa (DURÁN 2002, II:189), which was a certain solution to this problem: sometimes the person did not sell himself/herself on his/her own, but he/she was sold by another person with whom the former person had a strong juridical relation (marriage).

The sale of a child into slavery by his/her parents. Parents could sell their child into slavery if they were unable to support him/her or if he was "incorrigible" (i.e. unmanageable for his problematic behaviour), but in both cases (certainly in the second case) it seems that only with the permission of the court (ALBA 1949:33). There were probably only male descendants among the "incorrigible" children sold into slavery.

It is possible that the poverty of the family, whatever serious it was, was not yet a sufficient reason to sell a child into slavery, as parents perhaps could only sell (one) their child into slavery if they had more than four children (cf. DURÁN 2002, II:189).

The fate of a child sold into slavery was not irreversible. Parents had the opportunity to redeem their child from slavery as soon as their economic circumstances allowed it (see e.g. DURÁN 2002, I:296-297). They could also free their child from slavery by replacing him/her with his/her younger sibling. Finally, the enslaved child could gain freedom by working off his/her purchase price (VYŠNÝ 2019:159). 
Institution of huehuetlahtlacolli. It was based on a contract by virtue of which a family (or several families) provided permanently the other party, a wealthy person, one of the family members as a tlacohtli, in exchange for food aid or certain economic benefit regularly provided by this person to the family (TORQUEMADA 1969:565).

The enslaved member of the family remained living in his/her house in the circle of his/her family, meeting with his/her master only when he/she performed certain work for him/her (in his/her master's household, on his/her master's land and the like) (KATZ 1989:282), which, however, he/she was not supposed to do on a daily basis (TORQUEMADA 1969:563). On the other hand, he/she had to work whenever the master ordered him/her.

The obligated family could at any time replace its enslaved member with another one (TORQUEMADA 1969:563, 565). If the enslaved family member died or fell ill and was unable to work, the family was obliged to immediately replace him/her with one of its members (TORQUEMADA 1969:565).

If the tlacohtli died in his/her master's house, or if the master seized something from the property of his/her tlacohtli without his/her consent, the huehuetlahtlacolli ceased to exist (TORQUEMADA 1969:565).

The duration of the contract by which the huehuetlahtlacolli arose in individual cases was not limited. Thus, huehuetlahtlacolli was hereditary slavery indeed: the obligation of the family to provide a tlacohtli passed from generation to generation and, conversely, the right to use the services of that tlacohtli passed on heirs of the wealthy person who had concluded the contract of huehuetlahtlacolli (SAHAGÚN 2001, II:626).

As the institution of huehuetlahtlacolli had expanded considerably over time and burdened a large part of the population, Nezahualpilli, the tlatoani (ruler) of Tezcoco, abolished it in 1505 (IXTLILXOCHITL 1997, II:171), soon followed by Motecuhzoma II, the tlatoani of Tenochtitlan (TORQUEMADA 1969:565).

The forms of contractual slavery described above for many individuals and families were the only means of resolving their unfavorable economic situation, especially in recurring times of drought and famine. For example, the chronicler Durán states that in the early 50s of the $15^{\text {th }}$ century, due to a serious food crisis many inhabitants of Tenochtitlan left for other places, where "[t] hey sold their sons and daughters to merchants or to noblemen who could maintain them. A mother or father would trade a child for a small basket of maize, and the new owner was obliged to house and feed the infant while the famine lasted. If the parents wished to ransom him later, they would have to pay for all his maintenance" (DURÁN 2002, I:296297).

DOI: 10.2478/eas-2021-0012 C University of SS. Cyril and Methodius in Trnava. All rights reserved. 
Penal Slavery. The temporary enslaved debtors, as well as individuals sold into temporary slavery became tlatlacotin more or less voluntarily (by virtue of a contract) and with the intention to dispose of debts or improve the economic situation of them and their families. In contrast, the penal slavery rested on an involuntary, state-organized and long-term (sometimes even lifelong) enslavement of the perpetrators of certain crimes, that is, this slavery was a type of punishment imposed by courts in criminal proceedings.

The offenders sentenced to slavery were mostly converted to tlatlacotin of the victims of their crimes or to tlatlacotin of surviving relatives of persons they had killed (MARGADANT 2006:31). The victims or surviving relatives thus obtained a double satisfaction for what they had suffered, to wit: a moral one, as well as a material one (enslaved offenders were obliged to work for victims or their surviving relatives; moreover, they could be sold to third party by these persons).

There were various legally defined crimes punished by enslavement in Tenochtitlan or Tezcoco. However, in Tenochtitlan the judges could also sentence perpetrators of crimes to slavery at their discretion to some extent (VYŠNÝ 2019:144).

Among the concrete crimes punished by enslavement principally were: treason (the enslavement of traitor's descendants to the fourth generation); abuse of power by state officials; public drunkenness (an individual belonging to macehualtin caught drunk in public was enslaved; being caught drunk in public second time, he/she was executed); sale of parents' fortune without their approval or wasting inheritance by individuals belonging to macehualtin; the sale of not own child into slavery; the murder (the murderer was forgiven by the relatives of the murdered person, thus converting himself into their tlacohtli for life instead of being executed); killing a tlacohtli of another person (who killed a tlacohtli of another person, albeit unintentionally, became a tlacohtli to his/her master); less serious theft (however, thieves who did not return or refund the stolen items to their owners were not, in principle, enslaved, but executed; on the other hand, were the stolen things of little value such as no more than twenty pieces of agave, fishnet or boat the thieves were not enslaved on condition they paid a fine); and defraudation (see VYŠNÝ 2019:207ff.).

After examining the forms of slavery, we move on to the social and legal position of Nahua tlatlacotin destined for work. 


\section{Social and Legal Position of Slaves Destined for Work}

The main duty of tlatlacotin was to work for their masters. As we will see below, tlatlacotin had several important rights as well as more opportunities to gain freedom, but "incorrigible slaves" and enslaved criminals had the opportunity to gain it significantly limited (cf. DURÁN 2002, II:188), and therefore remained tlatlacotin for a long time, or even for lifetime sometimes.

The specific rights and obligations of tlatlacotin and their masters can be summarized as follows.

The tlacohtli could not be elected to any office belonging to the self-government body of the urban district (calpulli), he/she lived in (CRUZ BARNEY 2006:30).

The master was obliged to provide his tlacohtli with food, clothing and sometimes accommodation (SCHLENTHER 1975:30). Naturally, he/she did not reward him/her for his/her work, as it was aimed at settling the debt.

The tlacohtli worked for the benefit of his/her master either in master's house to which he/she moved or in his/her own house (ALBA 1949:34). When performing work for the master, the tlacohtli was obliged to follow his/her instructions or requirements.

A tlacohtli could marry both a tlacohtli or a free person and could have his/her family whose members were not tlatlacotin of his/her master, that is, they were free persons (KATZ 1989:280).

Movable and immovable property which belonged to a person before his/her enslavement, as well as that which he/she may have acquired as a tlacohtli, did not belong to the slave's master without the slave's consent (LÓPEZ DE GÓMARA 1997:310). Although it seems obvious that the tlacohtli used these assets to speed up the repayment of his/her debt, this did not always have to be the case, as it could often be necessary to leave them to tlacohtli's family members to have something to live on.

Tlatlacotin could have their own tlatlacotin whom they controlled independently from their masters (TORQUEMADA 1969:563).

The master's power over the tlacohtli did not include power over his/her life and death. Therefore, if the master killed his/her tlacohtli, he/she was responsible for it as if he/she had killed a free person. He/she was also responsible for inflicting bodily harm on a tlacohtli (KATZ 1989:280). The masters did not, in principle, treat their tlatlacotin disproportionately harshly (CLAVIJERO 2003:310) and apparently did not even force them to perform their duties with corporal punishment.

DOI: 10.2478/eas-2021-0012 C University of SS. Cyril and Methodius in Trnava. All rights reserved. 
The master could sell his/her tlacohtli only with his/her consent (MENDIETA Y NÚÑEZ 1992:88), except in two cases: first, the insolvent debtor, who became a tlacohtli to his/her creditor, the creditor could also sell against his/her will, and the robbed person could do the same with the enslaved thief who had robbed him/her (KOHLER 2002:72-73); secondly, the tlacohtli could be sold against his will if he was the so-called "incorrigible slave".

"Incorrigible slaves" were probably only male tlatlacotin. An "incorrigible slave" was considered to be a tlacohtli who was rebellious, did not work properly or ran away from his master's house, and who did not change his bad behavior even after his master repeatedly (three times) severely rebuked him in the presence of witnesses. A tlacohtli who fell into the category of " incorrigible slaves" lost some rights. His master set up a wooden or other yoke around his neck and took him to the market, where he sold him. If the sold tlacohtli did not improve his bad behavior while being with his new master, the new master could sell him to another person for this reason, who could also sell him for the same reason. However, it is likely that the threat of forced sale sooner or later caused "incorrigible slaves" to behave as expected, as a tlacohtli who was sold three times because of his "incorrigibility" could end up as a sacrifice to the gods (ALBA 1940:34).

The slave status of a man or woman lasted mostly only temporarily, however, there were three exceptions to this, concerning the institution of huehuetlahtlacolli, "incorrigible slaves" and enslaved criminals.

If a tlacohtli died before he had completely worked off or otherwise completely settled his debt, his master could satisfy the remaining part of his claim from slave's fortune, but in Tezcoco, as well as in Tenochtitlan, since 1505 he had no right to enslave the slave's wife or descendants (against their will) and force them to work in place of the deceased slave (KOHLER 2002:70-71; LÓPEZ DE GÓMARA 1997:309; IXTLILXOCHITL 1997, II: 171).

Tlatlacotin could gain freedom in the following ways:

A tlacohtli had completely worked off what he/she owed to his/her master, or a price at which he/she was sold, or he/she sold himself/herself into slavery, or a price at which he/she was sold to a new master.

The tlacohtli repaid additionally his/her debt (its remaining part, respectively), utilizing assets he/she had obtained as inheritance, as a gift or loan (MARGADANT 2006:31). In this way, however, the tlacohtli could acquire freedom only if he/she additionally had repaid his/her debt (its remaining part, respectively) before his/her second forced sale took place (ALBA 1949:35). 
The enslaved thief, before being sold for the second time, returned the stolen item or paid its value (KOHLER 2002:74-75).

The slave master died at a time when the tlacohtli had already partially settled his/her debt. In this case, not only the tlacohtli was freed, but he/she was also released from the obligation to pay the rest of the debt to the heir of his/her deceased master (ALBA 1949:34).

Parents redeemed their child from slavery, to which they had sold him/her because of their serious poverty (ALBA 1949:34-35). However, if parents had sold their son declared "incorrigible“ by a court, they probably could not redeem him later (KOHLER 2002:75).

The slave's master fell into poverty and his/her tlacohtli sold something of his/her fortune in order to aid his/her master (TORQUEMADA 1969:567).

The tlacohtli had a relationship (and possibly also children) with his female master (a widow) or married her, and vice versa (DURÁN 2002, II:191-192).

A tlacohtli was freed by the testament of his/her deceased master. However, if the master did not liberate the tlacohtli by the testament, the tlacohtli became part of the heritage left behind by the deceased master, that is, master's heir became the new master of the tlacohtli (TORQUEMADA 1969:567). It seems that sometimes tlatlacotin were killed after the death of their masters (KATZ 1956:129-130).

The tlacohtli was freed by his/her still-living master (LÓPEZ AUSTIN 1961:76).

A tlacohtli liberated himself/herself by giving another tlacohtli to his/her master with his consent (ALBA 1949:35).

The male tlacohtli succeeded in trying to escape from the marketplace to which he was entitled if he was to be sold there against his will. Under penalty of enslavement, no one could try to stop the fleeing slave, except for slave's master or master's son. The fleeing tlacohtli first ran out of the reserved area of the marketplace, where he deliberately stepped into excrement, and thus dirtied he continued to run towards the palace of the tlatoani (ruler), where he informed certain dignitaries that he was a tlacohtli on the run. The dignitaries took the yoke off the tlacohtli, stripped him naked, washed him from head to toe, dressed in clean clothes and introduced him to the tlatoani (DURÁN 2002, II:191). Since the enslavement of a man was seen as making him "dirty" (hence stepping into excrement by the fleeing slave to demonstrate that he was a "dirtied" man), the liberation of a tlacohtli had to be an opposite (ritual) action, to wit his cleansing. Once the "dirt" of the tlacohtli was washed away, he became again both physically and morally "pure" man and thus a normal human being, as well as a free person (see LÓPEZ AUSTIN 2004:461-464). For its part, the presentation of 
the freed tlacohtli to the ruler was an appreciation of his combativeness (his brave fight for freedom), which was considerably prised in the pre-Hispanic Nahua society.

A person which had illegally been enslaved could be liberated by a high Tenochtitlan court called tlacxitlan (SAHAGÚN 2001, II:663).

It seems that "incorrigible slaves", enslaved criminals and "incorrigible" sons sold into slavery could gain freedom only in ways mentioned under points I) to K) (cf. ALBA 1949:34$35)$.

\section{Conclusion}

It is clear from the foregoing that Nahua tlatlacotin destined for work have differed to a large extent from the standard Western notion of slaves. In the history of the Occident a slave was little more than a "speaking instrument" (instrumentum vocale). Lacking entirely or (in some instances) almost entirely the legal subjectivity, he/she was juridically an integral part of his/her master's fortune. From a juridical point of view, it is true, a slave was not a person (a free independent individual who is a subject of law and thus both has and can exercise certain rights), but a thing (object of law) subordinated to his/her master's extensive power. However, Nahua tlatlacotin (those who were destined for work) were subjects of law, although in some contexts (consider, for example, the self-enslavement) they were objects of law at the same time.

Being a subject of law, Nahua tlacohtli had a certain degree of personal freedom and certain rights. On the other hand, his/her personal freedom and freedom of residence and movement, as well as his/her right to decide freely on the use of his/her workforce and his/her right to work to provide for his/her family, were restricted, otherwise the tlacohtli could hardly work effectively for his/her master.

Likewise, enslaved persons had the legal capacity to perform legal acts, however, in practice they could not perform such legal acts that would prevent them from proper fulfilment of their duties to their masters. The tlatlacotin were also responsible (and punished) for their offenses against third parties, not their masters.

It is noteworthy to mention that the descendants of tlatlacotin (both sexes) were free. A person could become a tlacohtli by his/her birth only if he/she was the son/daughter, grandson/granddaughter or great-grandson/great-granddaughter of an executed traitor or if he/she was born to a family burdened with the contract of huehuetlahtlacolli. 
Peter VYŠNÝ

In general, the treatment of Nahua tlatlacotin - compared to the living conditions of their counterparts in many other world cultures - was significantly better, more humane. This can be seen, on the one hand, from the fact that the master was entitled only to his/her tlacohtli's labor and not to tlacohtli's life, health, family members or property, and, on the other hand, from the fact that the tlacohtli could gain freedom in many ways, not only by the manumission made by his/her master depending on master's good will. Although tlatlacotin were considered a kind of both physically and mentally "less perfect" individuals who were "dirtied", that is, morally tainted and dishonored by their enslavement and its reasons (mainly a delinquent behavior, i.e. non-payment of debts or perpetration of certain crimes), they were not systematically excluded from the wider society formed by free persons and they lived with their families in their houses and neighborhoods.

Thus, the translation of the Nahua term tlatlacotin by the term "slaves" is problematic and even misleading. However, such a translation is common in both colonial source texts and modern professional literature and therefore it would not be useful to replace it with another translation.

\section{Bibliography}

AGUILAR-MORENO, Manuel (2007): Handbook to Life in the Aztec World. New York: Oxford University Press.

ALBA, Carlos H. (1949): Estudio comparado entre el derecho azteca y el derecho positivo mexicano. México: Instituto Indigenista Interamericano.

BERDAN, Frances F. (2014): Aztec Archaeology and Ethnohistory. New York: Cambridge University Press.

BOONE, Elizabeth H. (2007): Cycles of Time and Meaning in the Mexican Books of Fate. Austin: University of Texas Press.

BOSCH GARCÍA, Carlos (1944): La Esclavitud Prehispánica. México: El Colegio de México, Centro de Estudios Históricos.

CASTILLO FARRERAS, Víctor M. (1996 [1972]): Estructura económica de la sociedad mexica según las fuentes documentales. México: Universidad Nacional Autónoma de México, Instituto de Investigaciones Históricas.

CASTILLO FARRERAS, Víctor M. (2010): Los conceptos nahuas en su formación social. El proceso de nombrar. México: Universidad Nacional Autónoma de México, Instituto de Investigaciones Históricas. 
Peter VYŠNÝ

Pre-Hispanic Nahua Slavery

CERVERA OBREGÓN, Marco Antonio (2017): Derecho en la guerra: el trato a los combatientes y no combatientes en los conflictos armados mexicas. In Reflectio. Revista de la Facultad de Humanidades, Filosofía y Letras de la Universidad Anáhuac México V. (9), pp. 74-88.

CLAVIJERO, Francisco Javier (2003): Historia antigua de México. México: Ed. Porrúa.

CLENDINNEN, Inga (1991): Aztecs: An Interpretation. Cambridge: Cambridge University Press.

CRUZ BARNEY, Oscar (2006): Historia del derecho en México. México: Oxford University Press.

DURÁN, Diego (2002): Historia de las Indias de Nueva España e Islas de Tierra Firme, I. México: Consejo Nacional para la Cultura y las Artes.

DURÁN, Diego (2002): Historia de las Indias de Nueva España e Islas de Tierra Firme, II. México: Consejo Nacional para la Cultura y las Artes.

FARGHER, Lane F. - BLANTON, Richard E. (2007): Revenue, Voice, and Public Goods in Three Pre-Modern States. In Comparative Studies in Society and History 49 (4), pp. 848-882.

GARZA, Mercedes de la (1978): El hombre en el pensamiento religioso náhuatl y maya. México: Universidad Nacional Autónoma de México, Instituto de Investigaciones Filológicas, Centro de Estudios Mayas.

GONZÁLEZ TORRES, Yóllotl (1985): El sacrificio humano entre los mexicas. México: Instituto Nacional de Antropología e Historia; Fondo de Cultura Económica.

GRAULICH, Michel (2002): Les victimes du sacrifice humain aztèque. In Civilisations. Revue internationale d'anthropologie et de sciences humaines 50, pp. 91-114.

HICKS, Frederic (1974): Dependent Labor in Prehispanic Mexico. In Estudios de Cultura Náhuatl 11, pp. 243-266.

HICKS, Frederic (1976): Mayeque y calpuleque en el sistema de clases del México antiguo. In Pedro Carrasco, Johanna Broda (eds.): Estratificación social en la Mesoamérica prehispánica. México: Secretaría de Educación Pública, Instituto Nacional de Antropología e Historia, pp. 67-77.

HINZ, Eike (1992): Kritische Rekonstruktion aztekischer Denk- und Handlungsstrukturen. In Indiana 12, pp. 55-75.

IXTLILXOCHITL, Fernando de Alva (1997): Obras Históricas. Tomo I. México: Instituto Mexiquense de Cultura; Universidad Nacional Autónoma de México, Instituto de Investigaciones Históricas. 
Peter VYŠNÝ

Pre-Hispanic Nahua Slavery

IXTLILXOCHITL, Fernando de Alva (1997): Obras Históricas. Tomo II. México: Instituto Mexiquense de Cultura; Universidad Nacional Autónoma de México, Instituto de Investigaciones Históricas.

IZQUIERDO, Ana Luisa (1984): La esclavitud en Mesoamérica: concepto y realidad. In José Luis Soberanes Fernández (coord.): Memoria del II Congreso de Historia del Derecho Mexicano. México: Universidad Nacional Autónoma de México, Instituto de Investigaciones Jurídicas, pp. 361- 374.

JOHANSSON K., Patrick (2010): Miquiztlatzontequiliztli. La muerte como punición o redención de una falta. In Estudios de Cultura Náhuatl 41, pp. 91-136.

KARTUNNEN, Frances (1992): An Analytical Dictionary of Nahuatl. Norman: University of Oklahoma Press.

KATZ, Friedrich (1956): Die sozialökonomischen Verhältnisse bei den Azteken im 15. und 16. Jahrhundert. In Ethnographisch-Archäologische Forschungen 3 (2), pp. 9-166.

KATZ, Friedrich (1989): Staré americké civilizace. Praha: Odeon.

KOHLER, Josef (2002): El derecho de los aztecas. México: Tribunal Superior de Justicia del Distrito Federal.

LAS SIETE PARTIDAS (1555). Qvarta Partida, titulos V, XXI-XXIII [online] https://www.boe.es/biblioteca_juridica/abrir_pdf.php?id=PUB-LH-2011-60_2.

LAS CASAS, Bartolomé de (1552): Tratado sobre la materia de los indios que se han hecho esclavos [online], https://www.biblioteca.org.ar/libros/131622.pdf.

LEÓN-PORTILLA, Miguel (1993): La Filosofía Náhuatl estudiada en sus fuentes. México: Universidad Nacional Autónoma de México, Instituto de Investigaciones Históricas.

LEVIN ROJO, Danna - NAVARRETE LINARES, Federico (coordinación, introducción): (2007): Indios, mestizos y españoles. Interculturalidad e historiografía en la Nueva España. México: Universidad Autónoma Metropolitana-Azcapotzalco, Universidad Nacional Autónoma de México, Instituto de Investigaciones Históricas.

LOCKHART, James (1985): Some Nahua Concepts in post-Conquest Guise. In History of European Ideas 6 (4), pp. 465-482.

LOCKHART, James (1992): The Nahuas After the Conquest. A Social and Cultural History of the Indians of Central Mexico, Sixteenth Through Eighteenth Centuries. Stanford: Stanford University Press.

LÓPEZ-AMO Y MARÍN, Ángel (1956): El derecho penal español de la Baja Edad Media. In: Anuario de la historia del derecho español 26, pp. 337-368. 
Peter VYŠNÝ

Pre-Hispanic Nahua Slavery

LÓPEZ AUSTIN, Alfredo (1961): La Constitución Real de México-Tenochtitlan. México: Universidad Nacional Autónoma de México, Instituto de Historia.

LÓPEZ AUSTIN, Alfredo (2004): Cuerpo humano e ideología. Las concepciones de los antiguos nahuas, I. México: Universidad Nacional Autónoma de México, Instituto de Investigaciones Antropológicas.

LÓPEZ AUSTIN, Alfredo (2015): Sobre el concepto de cosmovisión. In Alejandra Gámez Espinosa, Alfredo López Austin (coords.): Cosmovisión mesoamericana. Reflexiones, polémicas y etnografías. México: El Colegio de México, pp. 17-51.

LÓPEZ DE GÓMARA, Francisco (1997): Historia de la Conquista de México. México: Editorial Porrúa.

LÓPEZ HERNÁNDEZ, Miriam (2012): Ahuianime: las seductoras del mundo nahua prehispánico. In Revista española de antropología americana 42 (2), pp. 401-423.

MARGADANT S., Guillermo F. (2006): Introducción a la Historia del Derecho Mexicano. México: Esfinge.

McKEEVER FURST, Jill L. (1997): The Natural History of the Soul in Ancient Mexico. New Haven: Yale University Press.

MENDIETA Y NÚÑEZ, Lucio (1992): El derecho precolonial. México: Editorial Porrúa.

MILLHAUSER, John K. (2017): Debt as a Double-edged Risk: A Historical Case from Nahua (Aztec) Mexico. In Economic Anthropology 4, pp. 263-275.

MORENO, Manuel (1931): La Organización Política y Social de los Aztecas. México: Universidad Nacional.

MOTOLINÍA, Toribio de Benavente (1970): Memoriales e Historia de los Indios de la Nueva España. Madrid: Atlas.

OLIVIER, Guilhem (2003): Mockeries and Metamorphoses of an Aztec God: Tezcatlipoca, "Lord of the Smoking Mirror". Boulder: University Press of Colorado.

PREM, Hanns J. (1990): Kalender und Schrift. In Ulrich Köhler (Hrsg.): Altamerikanistik: Eine Einführung in die Hochkulturen Mittel- und Südamerikas. Berlin: Dietrich Reimer, pp. 241-253.

ROMERO GALVÁN, José Ruben (coordinación) (2011): Historiografía mexicana. Volumen I. Historiografía novohispana de tradición indígena. México: México, Universidad Nacional Autónoma de México, Instituto de Investigaciones Históricas.

SAHAGÚN, Bernardino de (2001): Historia general de las cosas de la Nueva España, I. Madrid: Dastin. 
Peter VYŠNÝ

Pre-Hispanic Nahua Slavery

SAHAGÚN, Bernardino de (2001): Historia general de las cosas de la Nueva España, II. Madrid: Dastin.

SCHLENTHER, Ursula (1975): Bodenbesitzverhältnisse und Tribute bei den Inka und Azteca. Mit einer sprachlichen Analyse und dem Vergleich der sozialen, ökonomischen und politischen Verhältnisse. In Ethnographisch-Archäologische Zeitschrift 16, pp. 1-83.

SMITH, Michael E. (2012): The Aztecs. Hoboken, NJ: Wiley - Blackwell.

SMITH, Michael E. - HICKS, Frederic (2016): Inequality and Social Class in Aztec Society. In Deborah L. Nichols, Enrique Rodriguez-Alegria (eds.): Oxford Handbook of the Aztecs. New York: Oxford University Press, pp. 425-436.

SHADOW, Robert D. - RODRÍGUEZ V., María J. (1995): Historical Panorama of Anthropological Perspectives on Aztec Slavery. In Barbro Dahlgren de Jordán, María de los Dolores Soto de Arechavaleta (eds.): Arqueología del norte y del occidente de México: Homenaje al Doctor J. Charles Kelley. Mexico City: Instituto de Investigaciones Antropológicas, Universidad Nacional Autónoma de México, pp. 299-323.

TESTART, Alain - JACOBS, Amy (2002): The Extent and Significance of Debt Slavery. In Revue française de sociologie 43, supplément. An annual english selection, pp. 173204.

TORQUEMADA, Juan de (1969): Monarquía Indiana. Tomo segundo. México: Porrúa.

TRIGGER, Bruce G. (2007): Understanding Early Civilizations. A Comparative Study. New York: Cambridge University Press.

VAILLANT, George C. (1941): Aztecs of Mexico: Origin, Rise and Fall of the Aztec Nation. Garden City: Doubleday Doran.

VON MENTZ, Brígida (2007): Esclavitud y semiesclavitud en el México antiguo y la Nueva España (con enfásis en el siglo XVI). In Stvdia Historica. Historia antigua 25, pp. 543-558.

VYŠNÝ, Peter (2019): El derecho en Tenochtitlan. Aspectos jurídicos del orden social de una ciudad-estado prehispánica. Praha: Leges. 
Peter VYŠNÝ is a legal historian. He graduated from Comenius University, Faculty of Law (2004). He received his first PhD. in Theory and History of State and Law from Trnava University (2009) and his second PhD. in IberoAmerican Studies from Charles University (2018). He works as an associate professor at the Department of Legal History, Faculty of Law, Trnava University. His research and publishing activities, as well as his teaching are focused on World Legal History in general, and in particular on selected topics of both Latin American and European legal histories.

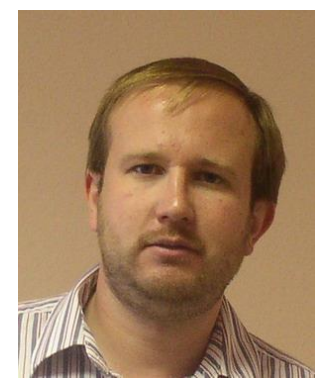

